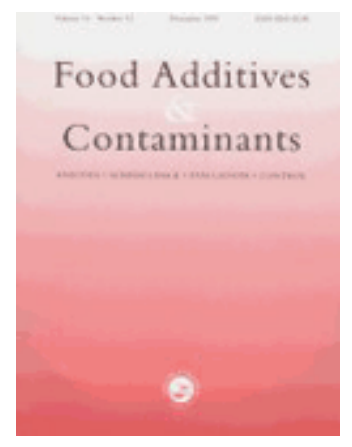

\title{
Immunochemical determination of gluten in malts and beers
}

\begin{tabular}{|r|l|}
\hline Journal: & Food Additives and Contaminants \\
\hline Manuscript ID: & TFAC-2005-365.R1 \\
\hline Manuscript Type: & Original Research Paper \\
\hline Author: & 29-Mar-2006 \\
\hline Complete List of Authors: & $\begin{array}{l}\text { Dostálek, Pavel; Institute of Chemical Technology, Prague, } \\
\text { Department of Fermentation Chemistry and Bioengineering } \\
\text { Hochel, Igor; Institute of Chemical Technology, Prague, Department } \\
\text { of Biochemistry and Microbiology } \\
\text { Méndez, Enrique; Centro Nacional de Biotecnologia, Unidad de } \\
\text { Gluten } \\
\text { Hernando, Alberto; Centro Nacional de Biotecnologia, Unidad de } \\
\text { Gluten } \\
\text { Gabrovská, Dana; Food Research Institute Prague, Department of } \\
\text { Nutritive Substances }\end{array}$ \\
\hline Methods/Techniques: & Immunoassays \\
\hline Fdditives/Contaminants: & Allergens \\
\hline \hline
\end{tabular}

\section{SCHOLARONE ${ }^{\text {M }}$ Manuscripts}




\title{
Immunochemical determination of gluten in malts and beers
}

\author{
P. Dostálek ${ }^{1}$, I. Hochel ${ }^{1}$, E. Méndez ${ }^{3}$, A.Hernando ${ }^{3}$, \\ D. Gabrovská ${ }^{1,2}$
}

${ }^{1}$ Institute of Chemical Technology Prague, Technická 5, CZ-166 28, Praha 6, Czech Republic

${ }^{2}$ Food Research Institute Prague, Radiová 7, CZ-110 00 Praha 10, Czech Republic

${ }^{3}$ Unidad de Gluten, Centro Nacional de Biotecnologia (CSIC), Campus de la Univesidad Autonóma, Cantoblanco, Madrid, Spain

Correspondence: Pavel Dostálek, Institute of Chemical Technology Prague, Technická 5, 166 28, Praha 6, Czech Republic. E-mail: Pavel.Dostalek@vscht.cz 


\begin{abstract}
The gluten content in the different varieties of barley, malts, and different types of beers were determined by means of "sandwich" enzyme immunoassay (RIDASCREEN $^{\circledR}$ Gliadin kit). The gluten levels in barley wheat, rye and spelt malts ranged from 18.8-45.0, 44.0-68.0, 41.6, and $21.2 \mathrm{~g} \cdot \mathrm{kg}^{-1}$, respectively. When various types of beer were compared the gluten concentration increased as follows: alcohol free beer $(<3.0)$, lager beers $\left(<3.0-8.7 \mathrm{mg} \mathrm{l}^{-1}\right)$, stouts $\left(9.0-15.2 \mathrm{mg} \mathrm{l}^{-1}\right)$ and wheat beers (10.6-41.2 $\left.\mathrm{mg} \mathrm{l}^{-1}\right)$. Ten Czech lager beers were analysed using both sandwich and competitive ELISA and the results were compared. The latter method provided several times higher values then former one. Gluten balance was carried out during the brewing process starting from raw materials and terminating at the final beer. The amount of protein decreased due to precipitation of protein during the mashing process, primary and secondary fermentation and lastly as a result of adsorption during beer stabilization. The gluten content in beer is thus approximately three orders of magnitude lower than that in the raw malt.
\end{abstract}

Keywords: Gluten, gliadin, peptide, protein, beer, malt, barley, wheat, prolamin content, coeliac disease

\title{
Introduction
}

Coeliac disease $(\mathrm{CD})$ is a digestive disease that damages the small intestine and interferes with absorption of nutrients from food (Lewis 2005). People who suffer from CD cannot tolerate a protein called gluten, which is found in wheat, rye, barley, and possibly oats. Gluten consists generally from prolamin and glutelin proteins. Wheat prolamin is known as gliadin and barley prolamin as hordein. When people 
with $\mathrm{CD}$ eat foods containing gluten, their immune system responds by damaging the small intestine. Specifically, tiny finger-like protrusions, called villi, on the lining of the small intestine are lost. Nutrients from food are absorbed into the bloodstream through these villi. Without villi, a person becomes malnourished. Because the body's own immune system causes the damage, coeliac disease is considered as an autoimmune disorder (Lewis 2005). However, it is also classified as a disease of malabsorption because nutrients are not absorbed. If a person responds to the glutenfree diet (GFD), the physician will know for certain that the diagnosis of coeliac disease is correct. A GFD means avoiding all foods that contain wheat (including spelt and triticale), rye, barley, and possibly oats (Poms et al. 2004). Whether there is some maximum tolerable daily intake of gluten which can be estimated for treated coeliacs is an important issue. There is a study which suggests that $10 \mathrm{mg}$ should be considered as the maximum tolerable daily intake of gluten in treated coeliacs (Catassi et al. 2005). On the other hand, there is another study (Biagi et al. 2004) which reports that even a milligram of gluten a day keeps the mucosal recovery away. As each person suffering from $\mathrm{CD}$ has different tolerance to gluten ingestion, we cannot fix general safe daily intake limit for gluten.

With an annual consumption of almost 160 litres of beer per capita, the Czech Republic is the world's number one beer nation. Beer constitutes an important part of the diet for a significant section of the Czech population. Beer contains only about $0.3 \%$ proteins or polypeptides, the principal source of which is malt. Malt is produced mostly only from wheat or barley. These cereals, however, also comprise prolamins that are associated with CD. Knowledge about distribution and final levels of these proteins or their "toxic" fragments in beer is essential to ensure the safe consumption of this drink by coeliacs (Ellis et al. 1990; Ellis et al. 1994; Kanerva et al. 2005; 
Hernando et al. 2005). Comprehensive quantitative data on the gluten content of beers is still lacking, the same situation is for gluten balance during the brewing process. This study has been undertaken to find out whether beer contains any gluten that could be toxic to coeliacs.

\section{Materials and methods \\ Determination of gluten}

Two sandwich enzyme-linked immunosorbent assay (ELISA) commercial kits were used for gluten determination, the RIDASCREEN ${ }^{\circledR}$ Gliadin kit base on the monoclonal antibody R5 (Valdés et al. 2003; Méndez et al. 2005) (R-Biopharm AG, Darmstadt, Germany, prod. no. R 7001) and Gliadin ELISA kit based on two monoclonal antibodies (Gabrovská et al. 2003; Gabrovská et al. 2004; Gabrovská et al. 2006) (Immunotech a Beckman Coulter Company, Prague, Czech Republic, prod. No. IM3717) with a detection limit for gluten of 3 and $20 \mathrm{mg} \mathrm{kg}^{-1}$ respectively. The instructions manufacturers for their proper use were followed. As RIDASCREEN ${ }^{\circledR}$ Gliadin kit is effective for intact prolamins but not for hydrolysed ones, hydrolysed peptides in beers were also analysed by a home-made competitive ELISA kit based on R5 antibody (Ferre et al. 2004; Hernando et al. 2005). This system (Méndez, García and Ferre 2005) has a detection limit $6 \mathrm{ppm}$ of gluten, reproducibility $7.7 \%$, repeatability $4.7 \%$ and nearly quantitative recovery (90-96\%). Gliadin standard (PWG gliadin standard - candidate reference material - IRMM-480) was used for calibration (Van Eckert 2002).

\section{Sample preparation}

Five grams of grains or malts were grinded to powder. A $1.0 \mathrm{~g}$ amount of representative flour was extracted with $10 \mathrm{ml}$ of $60 \%(\mathrm{v} / \mathrm{v})$ ethanol solution by 
shaking for 30 minutes, followed by centrifugation at $2500 \mathrm{~g}$ for 30 minutes (Valdés et al. 2003). One $\mathrm{ml}$ of beer or brewing semiproducts (after removal of carbon dioxide) was mixed with $9 \mathrm{ml}$ of ethanol solution $(60 \% \mathrm{v} / \mathrm{v})$. Beers with low prolamin concentrations were concentrated by freeze-drying.

\section{Analyses of wheat, barleys, barley malts and malts from other cereals}

Eleven commercial malts made from barley, wheat, spelt and rye were analysed for gluten content. These commercial malts were purchased from Weyermann Specialty Malting Company (Bamberg, Germany). Five barley commercial malts were prepared from five different barley varieties by the same malting technological process in Nymburk malt house (Malteries Soufflet ČR, Plc., Czech Republic). All samples were analysed for gluten content by RIDASCREEN ${ }^{\circledR}$ Gliadin kit except of wheat and wheat malt samples, which were analysed by Gliadin ELISA kit.

\section{Technological trials - brewing the beer}

Beer for gluten balance trial was prepared in brewery pilot plant (50 litres of wort) in the Department of Fermentation Chemistry and Bioengineering in the Institute of Chemical Technology Prague. Mashing process was double mash process with mashing-in temperature of $50{ }^{\circ} \mathrm{C}$. Only barley malt of Pilsen type was used for mashing. Wort was separated by a classical lautering process. Hop boiling time was 90 minutes. Dried natural Czech Saaz hop was used only. Final wort bitterness was $35 \mathrm{BU}$ (EBC bitterness units - mg of bitter substances per litre of wort). After hot trub separation fermentation was carried out with bottom-fermenting yeast strain 95, purchased from Research Institute of Brewing and Malting, Plc. (Prague, Czech Republic), using $14.10^{6}$ viable cells per ml. The primary fermentation process took place at $12{ }^{\circ} \mathrm{C}$. A cold maturation was carried out for 21 days at $1{ }^{\circ} \mathrm{C}$. After kieselguhr 
filtration beer was stabilised by PVPP $\left(30 \mathrm{~g} \mathrm{hl}^{-1}\right)$ and by silica gel (Stabiquick strong $\left.30 \mathrm{~g} \mathrm{hl}^{-1}\right)$

\section{Analyses of beers}

Nineteen commercial beers which represent all principle brands of beers available on the Czech market were analysed for gluten content. All beers were analysed for gluten content by RIDASCREEN ${ }^{\circledR}$ Gliadin kit and only some beers with very low gluten content detected by RIDASCREEN ${ }^{\circledR}$ Gliadin kit were also analysed by competitive ELISA kit based on R5 antibody. One commercial beer was additionally treated for removal of proteins by silica gel - Stabiquick strong and Stabifix super $\left(2 \mathrm{~g} \cdot \mathrm{l}^{-1}\right)$ from Stabifix Braeurei-Technik (München, Germany). This trial was done for confirmation, if there is a possibility to reduce the level of gluten in final beer

\section{Results and discussion}

Barley (wheat), hop, yeast and water are basic raw materials for brewing the beer. Gluten or products of their hydrolysis detected in beer can come only from barley (wheat). Malt for production of beer is produced from barley and wheat by malting process, which consists of steeping, germination and kilning. The activities of amylase enzymes and proteolytic modification in grains increase during the malting process. Wheat and malt prepared from the wheat were analysed for gluten content. Wheat contained $50.4 \pm 1.8$ grams of gluten per $\mathrm{kg}$ and corresponding malt $68.0 \pm 4.0$ grams of gluten per kg. These gluten levels were determined by Gliadin ELISA kit in which the used antibody (against wheat gliadin) has cross-reactivity with barley prolamins only about 20\% (Gabrovská et al. 2004; Gabrovská et al. 2006). The higher level of gluten in malt compared to original grain is fully confirmed by analysis of gluten in three barley varieties from two different growing areas and the corresponding malt samples produced under the same malting conditions (Figure 1). 
[ Insert Figure 1 about here ]

\begin{abstract}
Gluten analysis of these samples was performed by RIDASCREEN ${ }^{\circledR}$ Gliadin kit. In this case, the used monoclonal antibody detects the gliadin fractions from wheat and corresponding prolamins from barley and rye (Valdés et al. 2003) equally. Content of gluten in cereals and malts are lower then the theoretical ones (Belitz et al. 2004) due to used analytical technique. These results were found also in previous work (Ellis at al. 1990). Table I shows gluten content in commercial cereal malts. The highest content of gluten was ascertained in wheat pale malt. The content of gluten in several kinds of barley malt varied from 18.8 to $45.0 \mathrm{~g} \mathrm{~kg}^{-1}$. The gluten content in spelt and rye malt ranged approximately over the same interval.
\end{abstract}

\author{
[ Insert Table I about here ]
}

The gluten balance was examined from raw materials to final beer during the brewing process (Table II). Total gluten content in malt, used for brewing beer, was $100 \%$ gluten source. Malt extract was transferred into solution during the mashing process in the brewing house. During the mashing process in the brewing house most of proteins were precipitated and only some proteins were spit into simple polypeptides (Lewis 2005). The majority of precipitated proteins remained in the spent grain after lautering process. Only a small part of gluten $(1.75 \%)$ passed from malt to sweet wort. Negligible consequent gluten depletion was noted in hopped wort after hop boiling $(1.70 \%)$. The $\mathrm{pH}$ decreased during the primary and secondary 
fermentation processes. It caused precipitation of some polypeptides and their adsorption onto the yeast cell surface (only $0.21 \%$ of the original gluten content remains in beer). After the filtration process beer is colloidally stabilised by removal of proteins and polyphenolic substances by adsorption on polyvinylpolypyrrolidone (PVPP) and kiesegel (silica gel). This process (less then $0.11 \%$ of original content of gluten) resulted in decreasing of gluten content (Table II).

[ Insert Table II about here ]

As shown in Table III, gluten level of commercial beers from the Czech market are very variable. The gluten concentration increases from alcohol free beer $(<3.0)$, lager beers $\left(<3.0-8.7 \mathrm{mg} \mathrm{l}^{-1}\right)$, stouts $\left(9.0-15.2 \mathrm{mg} \mathrm{l}^{-1}\right)$, to wheat beers $\left(10.6-41.2 \mathrm{mg} \mathrm{l}^{-}\right.$ $\left.{ }^{1}\right)$. The gluten content of some Czech lager beers analysed by sandwich RIDASCREEN $^{\circledR}$ Gliadin kit and by competitive ELISA kit based on R5 antibody are shown in Table IV. The both kits are based on R5 antibody. It is evident that not all Czech lager beers contain less than $20 \mathrm{mg}$ of gluten per litre. Since 1996, the legislation threshold for foods gluten-free by nature is $20 \mathrm{mg} \mathrm{kg}^{-1}$ of gluten $\left(10 \mathrm{mg} \mathrm{kg}^{-}\right.$ 1 of gliadin) (Deutsch 2005). The R5 antibody is capable of recognising several and small repetitive celiac-toxic epitopes QQPFP, LQPFP, QLPYP, QLPTP, QQSFP, QQTFP, PQPFP, QQPYP and PQPFP in prolamin molecules (Osman et al. 2001; Kahlenberg et al. 2006). The sandwich R5-ELISA needs at least two specific celiactoxic epitopes. Prolamins presented in beer are partially hydrolysed in fragments with one or a few celiac-toxic epitopes. Consequently these small fragments containing a single celiac-toxic epitope cannot be measured by the conventional sandwich R5- 
ELISA, hydrolysed prolamins are always underestimated. The efficiency of the competitive R5-ELISA over the sandwich is superior in quantifying hydrolysed prolamins as demonstrated in the analysis of beers in Table IV. The competitive R5ELISA yields prolamin contents higher than the sandwich ELISA. The competitive R5-ELISA is a reliable assay for determination of gluten-free beers based on wheat or barley malt extract as had been demonstrated in some beers based on barley malt and approved by the Finnish Coeliac Society for consumption by coeliacs (Hernando et al. 2005). Prolamins present in beer are partially hydrolysed and these small fragments always contain proline (Dale et al. 1989; Siebert 1999; Siebert and Lynn 2005). The haze-forming activity of a polypeptide in beer depends greatly on its proline content (Siebert 1999). Haze-forming polyphenols have at least two binding groups, each of which has at least two hydroxyl groups on an aromatic ring for binding of proline part of protein (Siebert 1999). As proline is structurally similar to pyrrolidone the PVPP can bind polyphenols (Siebert and Lynn 2005; Leiper et al. 2005). Measurement of prolamin concentration thus can represent excellent tool for prediction of colloidal beer stability (Siebert 1999; Siebert and Lynn 2005).

[ Insert Table III about here ]

[ Insert Table IV about here ]

\section{Conclusions}

Two commercial sandwich enzyme-linked immunosorbent assays (Gliadin ELISA kit and RIDASCREEN ${ }^{\circledR}$ Gliadin kit) and competitive ELISA kit were used for gluten determination in barley, wheat, malts and beers. Gliadin ELISA kit is applicable only

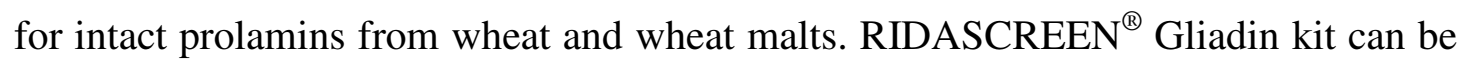


used for intact prolamins from wheat, barley and rye, while the competitive R5ELISA is ideal for testing hydrolysed wheat, barley and rye prolamins in beer.

The gluten level ranges in barley wheat, rye and spelt malts were found to be 18.8-45.0, 44.0-68.0, 41.6, and $21.2 \mathrm{~g} \mathrm{~kg}^{-1}$, respectively. The amount of these proteins, decreased from $100 \%$ in malt to less then $0.11 \%$ in stabilized beer during the mashing process, primary and secondary fermentation and stabilization process.

Gluten concentrations were found to increase from alcohol free beer $(<3.0)$, lager beers $\left(<3.0-8.7 \mathrm{mg} \cdot \mathrm{l}^{-1}\right)$, stouts $\left(9.0-15.2 \mathrm{mg} \cdot \mathrm{l}^{-1}\right)$, to wheat beers $\left(10.6-41.2 \mathrm{mg} \cdot \mathrm{l}^{-}\right.$ ${ }^{1}$ ). Only $84 \%$ of nineteen beer samples (analysed by RIDASCREEN ${ }^{\circledR}$ Gliadin kit) was safe for consumption of coeliacs from point of view legislation limit $\left(20 \mathrm{mg} \cdot \mathrm{l}^{-1}\right)$. The number of safe beer samples dramatically decreased to $30 \%$, if the samples were analysed by competitive ELISA. Nevertheless, there is no safe beer produced from barley or wheat regarding the maximum tolerable daily intake of gluten (10 $\mathrm{mg})$ and different tolerance of the patients suffering coeliac disease to gluten level.

\section{Acknowledgement}

This study was supported by the Ministry of Education, Youth and Sports of the Czech Republic (Research Centre 1M6215648902) and the Ministerio de Ciencia y Tecnología AGL2005-02721.

\section{References}

Belitz HD, Grosch W, Schieberle P. 2004. Food Chemistry. $3^{\text {rd }}$ ed. Berlin: SpringerVerlag. p 681. 
Biagi F, Campanella J, Martucci S, Pezzimenti D, Ciclitira PJ, Ellis HJ, Corazza GR. 2004. A milligram of gluten a day keeps the mucosal recovery away: A case report. Nutrition Reviews 62:360-363.

Catassi C, Fabiani E, Mandolesi A, Bearzi I, Iacono G, D’Agaste C, Francavilla R, Corraza GR, Volta U, Accomando S, Picarelli A, De Vitis I, Nardone G, Bardella MT, Fasano A, Pucci A. 2005. The Italian study on gluten microchallenge: preliminary results. Proceedings of the 19th Meeting Working Group on Prolamin Analysis and Toxicity (Verlag Wissenschafliche Scripten - edited by M.Stern), Prague, 2004, pp 109-114.

Deutsch H. 2005. Topic relating to Codex, Labelling and Symbol. Proceedings of the 19th Meeting Working Group on Prolamin Analysis and Toxicity (Verlag Wissenschafliche Scripten - edited by M.Stern), Prague, 2004, pp 171-175.

Ellis HJ, Freedman AR, Ciclitira PJ. 1990. Detection and estimation of the barley prolamin content of beer and malt to assess their suitability for patients with coeliac disease. Clinica Chimica Acta 189:123-130.

Ellis HJ, Doyle AP, Day P, Wieser H, Ciclitira PJ. 1994. Demonstration of the presence of coeliac-activating gliadin-like epitopes in malted barley. International Archives Allergy and Immunology 104:308-310.

Ferre S, García E, Méndez E. 2004. Measurement of hydrolysed gliadins by a competitive ELISA based on monoclonal antibody R5: analysis of syrups and beers. 
Proceedings of the 18th Meeting Working Group on Prolamin Analysis and Toxicity (Verlag Wissenschafliche Scripten - edited by M.Stern), Stockholm, Sweden, 2003, pp 65-69.

Gabrovská D, Rysová J, Burkhard M. 2003. Gluten-free diet and the situation in the Czech Republic. Proceedings of the 17th Meeting Working Group on Prolamin Analysis and Toxicity (Verlag Wissenschafliche Scripten - edited by M.Stern), London, UK, 2002, pp 135-138.

Gabrovská D, Rysová J, Burkhard M, Cuhra P, Kubík M, Baršová, S. 2004.

Collaborative study of a new developed ELISA kit for gluten determination. Journal of Food, Agriculture \& Environment 2:113-115.

Gabrovská D, Rysová J, Filová V, Plicka J, Cuhra P, Kubík M, Baršová S. 2006.

Gluten determination by gliadine enzyme-linked immunosorbent assay kit: Interlaboratory Study. Journal of AOAC International 89:154-160.

Hernando A, García E, Llorente M, Mujico J R, Lombardía M, Maki M, Kaukinen K, Collin P, Méndez E. 2005. Measurements of hydrolysed gliadins in malts, breakfast cereals, heated/hydrolysed foods, whiskies and beers by means of a new competitive R5 ELISA. Proceedings of the 19th Meeting Working Group on Prolamin Analysis and Toxicity (Verlag Wissenschafliche Scripten - edited by M.Stern), Prague, 2004, pp 31-37. 
Kahlenberg F, Sanchez D, Lachmann I, Tuckova L, Tlaskalova H, Mendez E, Mothes T. 2006. Monoclonal antibody R5 for detection of putatively coeliac-toxic gliadin peptides. European Food Research and Technology 222:78-82.

\begin{abstract}
Kanerva P, Sontag-Strohm T, Lehtonen P. 2005. Determination of Prolamins in Beers by ELISA and SDS-PAGE. Journal of the Institute of Brewing 111:61-64.
\end{abstract}

Lewis MJ. 2005. Celiac Disease, Beer, and Brewing. Technical Quarterly \& The MBAA Communicator 42:45-48.

Leiper KA, Stewart GG, McKeown IP, Nock T, Thompson MJ. 2005. Optimising Beer Stabilisation by the Selective Removal of Tannoids and Sensitive Proteins. Journal of the Institute of Brewing 111:118-127.

\begin{abstract}
Mendéz E, García E., Ferre L. 2005. Competitive ELISA for the detection of hydrolysed gluten and its applications. ES 2239545.
\end{abstract}

\begin{abstract}
Méndéz E, Vela C, Immer U, Janssen FW. 2005. Report of a collaborative trial to investigate the performance of the R5 enzyme linked immunoassay to determine gliadin in gluten-free food. European Journal of Gastroenterology and Hepatology $17: 1053-1063$.
\end{abstract}
Osman AA, Uhlig HH, Valdés I, Amin M, Méndez E, Mothes T. 2001. A monoclonal antibody that recognizes a potential coeliac-toxic repetitive pentapeptide epitope in gliadins. European Journal of Gastroenterology and Hepatology 13:1189-1193.


Poms RE, Klein CL, Anklam E. 2004. Methods for allergen analysis in food: a review. Food Additives \& Contaminants 21:1-31.

Siebert KJ. 1999. Effects of Protein-Polyphenol Interactions on Beverage Haze,

Stabilization and Analysis. Journal of Agricultural and Food Chemistry 47:353-362.

Siebert KJ, Lynn P.Y. 2005. Comparison of Methods for Measuring Protein in Beer. Journal of the American Society of Brewing Chemists 63:163-170.

Valdés I, Garcia E, Llorente M, Méndez E. 2003. Innovative approach to low-level gluten determination in foods using a novel sandwich enzyme-linked immunosorbent assay protocol. European Journal of Gastroenterology \& Hepatology 15:465-474.

Van Eckert R. 2002. The PWG gliadin, a new reference material. Proceedings of the 16th Meeting Working Group on Prolamin Analysis and Toxicity (Verlag Wissenschafliche Scripten - edited by M.Stern), Sitges, Spain, 2001, pp 25-27. 


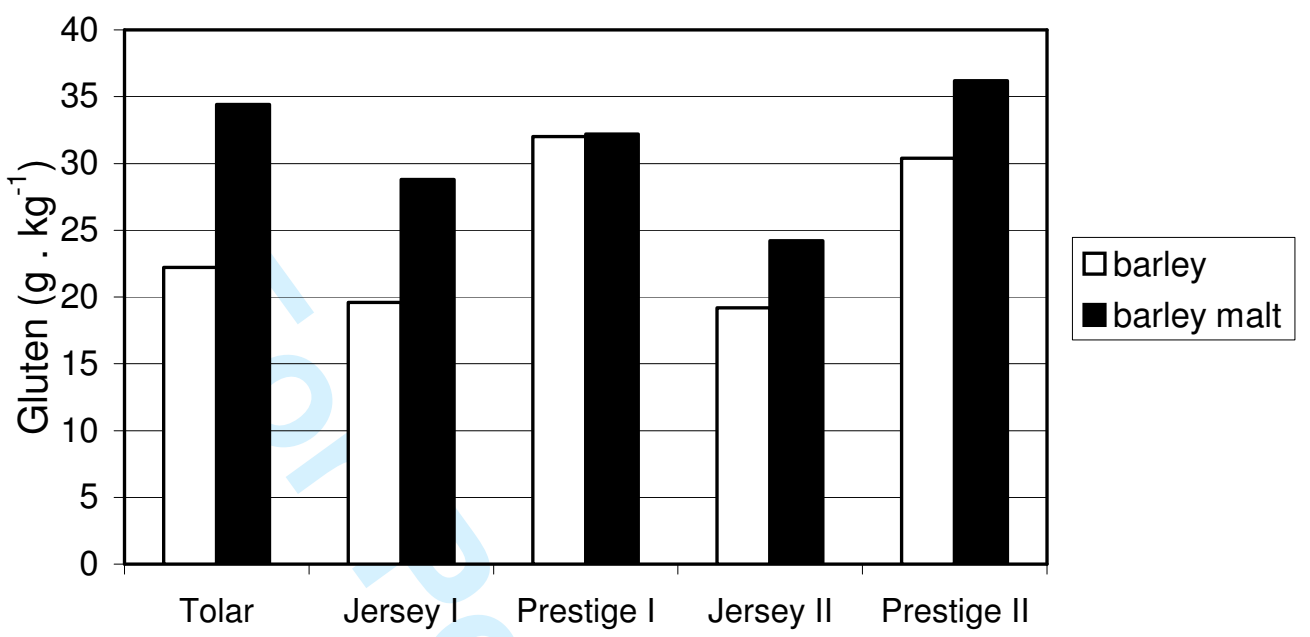

Figure 1. Content of gluten in some barley varieties and corresponding barley malts. Varieties I and II origin from different culture area (all samples were analysed by RIDASCREEN $^{\circledR}$ Gliadin kit). 
Table I. Mean content of gluten in some malt types

\begin{tabular}{|c|c|}
\hline Malt type & Gluten $\left(\mathrm{g} \mathrm{kg}^{-1}\right)^{\mathrm{ac}}$ \\
\hline Caraaroma (barley) & $42.0 \pm 0.2$ \\
\hline Melanoid (barley) & $20.4 \pm 0.2$ \\
\hline Cararred (barley) & $20.6 \pm 0.2$ \\
\hline Carafa (barley) & $45.0 \pm 0.2$ \\
\hline Pilsner (barley) & $18.8 \pm 0.6$ \\
\hline Smoked (barley) & $20.8 \pm 1.0$ \\
\hline Munich (barley) & $20.2 \pm 0.2$ \\
\hline Wheat chocolate (Wheat) ${ }^{b}$ & $44.0 \pm 1.6$ \\
\hline Wheat pale (Wheat) ${ }^{\mathrm{b}}$ & $68.0 \pm 4.0$ \\
\hline Spelt chocolate (Spelt) & $21.2 \pm 0.4$ \\
\hline Rye chocolate (Rye) & $41.6 \pm 1.4$ \\
\hline
\end{tabular}

${ }^{\mathrm{a}} \pm$ standard deviation $(\mathrm{n}=3) ; \quad{ }^{\mathrm{b}}$ Sample analysed by Gliadin ELISA kit
${ }^{\mathrm{c}}$ All samples except of wheat samples were analysed by RIDASCREEN ${ }^{\circledR}$ Gliadin kit 
Table II. Balance of gluten in course of the brewing process

\begin{tabular}{lll}
\hline Raw material, & Gluten $^{\mathrm{b}}\left(\mathrm{mg} \mathrm{kg}^{-1}\right)$ & $(\%)^{\mathrm{a}}$ \\
semiproducts, & & \\
product & & 100 \\
\hline Malt & 18780 & 1.75 \\
Sweet wort & 49.4 & 1.70 \\
Wort & 48.0 & \\
Beer & 6.0 & 0.21 \\
Stabilised beer & $<3.0$ & $<0.11$ \\
\hline
\end{tabular}

${ }^{\mathrm{a} C}$ Content of gluten in malt represents $100 \%$

${ }^{\mathrm{b}}$ All samples were analysed by RIDASCREEN ${ }^{\circledR}$ Gliadin kit. 
Table III. Content of gluten in beers from the Czech market

Beer $\quad$ Gluten $\left(\mathrm{mg} \mathrm{l}^{-1}\right)^{\mathrm{ab}}$

A - Czech alcohol free beer

$<3.0$

B - Czech lager beer

$<3.0$

C - Czech lager beer

$<3.0$

D - Czech lager beer

$6.6 \pm 0.2$

E - Czech lager beer

$8.7 \pm 0.4$

F - Czech lager beer

$4.2 \pm 0.4$

$\mathrm{G}-$ Czech lager beer

$4.4 \pm 0.4$

$\mathrm{H}$ - Czech lager beer

$<3.0$

I - Czech lager beer

$<3.0$

$\mathrm{J}$ - Czech lager beer

$<3.0$

$\mathrm{K}$ - Czech lager beer

$5.2 \pm 0.4$

L - Czech lager beer

$3.0 \pm 0.2$

M - Czech lager beer

$<3.0$

N - Belgium Belle Vue Kriek

$10.6 \pm 0.4$

$\mathrm{O}$ - Czech wheat beer

$23.6 \pm 1.8$

P - Belgian Hoegaarden wheat beer

$39.0 \pm 0.4$

Q - Czech wheat beer

$41.2 \pm 6.0$

$\mathrm{R}$ - Irish Guiness stout

$15.2 \pm 1.8$

S - Irish Murphy's stout

$9.0 \pm 0.6$

${ }^{\mathrm{a}} \pm$ standard deviation $(\mathrm{n}=3)$;

${ }^{\mathrm{b}}$ All samples were analysed by RIDASCREEN ${ }^{\circledR}$ Gliadin kit. 
Table IV. Content of gluten in some Czech lager beers (analysed by two methods)

Czech lager beer samples Gluten $\left(\mathrm{mg} \mathrm{kg}^{-1}\right)$

\section{RIDASCREEN $^{\circledR} \quad$ R5 competitive ELISA} sandwich ELISA

\begin{tabular}{|c|c|c|}
\hline A & $<3.0$ & 24.5 \\
\hline B & $<3.0$ & 28.3 \\
\hline 3 & $<3.0$ & 58.6 \\
\hline $\mathrm{D}$ & 6.6 & 102.1 \\
\hline $\mathrm{E}$ & 8.7 & 36.0 \\
\hline $\mathrm{F}$ & 4.2 & 22.0 \\
\hline G & 4.4 & 54.7 \\
\hline $\mathrm{H}$ & $<3.0$ & 11.0 \\
\hline I & $<3.0$ & $<6.0$ \\
\hline $\mathrm{J}$ & $<3.0$ & 11.0 \\
\hline $\mathrm{J}$ - treated by Stabiquick strong $\left(2 \mathrm{~g}^{-1}\right)$ & $<3.0$ & $<6.0$ \\
\hline $\mathrm{J}-$ treated by Stabifix super $\left(2 \mathrm{~g} \mathrm{l}^{-1}\right)$ & $<3.0$ & $<6.0$ \\
\hline
\end{tabular}


